\title{
ГИДРОХИМИЧЕСКИЙ СОСТАВ И СТРАТИФИКАЦИЯ ВОДЫ В ПОЙМЕННОМ ОЗЕРЕ ТАХТАРКА
}

\author{
М. Ю. Горбунов \\ Институт экологии Волжского бассейна РАН, Россия \\ Поступила в редакцию 1 июня 2018 г.
}

\begin{abstract}
Аннотация: Озеро Тахтарка, пойменное озеро в бассейне Дона, было исследовано в летние месяцы 2005, 2007, 2008 и 2016 г., и зимой 2018. В летний период в озере наблюдались значительные разности минерализации воды, достигающие 0,5 г/л, а также вторичные градиенты окислительно-восстановительного потенциала, концентраций сульфидов (более 2 мМ в придонном слое) и биогенных элементов, более характерные для эвксинных меромиктических водоемов. Несмотря на это, расчеты показали, что меромиктическая стабильность в озере недостаточна для надежного подавления его полного перемешивания в осенний период, а зимние наблюдения 2018 г. подтвердили этот вывод. Таким образом, озеро представляет собой очень динамичную в гидрохимическом плане систему, в которой ежегодно или почти ежегодно формируются и разрушаются значительные градиенты условий среды. В целом, озеро, видимо, можно отнести к редкой и недостаточно изученной группе озер с «весенним меромиксисом» и «нерегулярным перемешиванием».
\end{abstract}

Ключевые слова: пресные водоемы, пойменные озера, вертикальная стратификация, перемешивание, градиенты физико-химических параметров, меромиксис, нерегулярное полное перемешивание.

Abstract: The Takhtarka Lake, a floodplain lake in the Don River basin, was studied in the summer months of 2005, 2007, 2008 and 2016 and in winter of 2018. Great vertical differences of water salinity, up to $0.5 \mathrm{~g} \mathrm{~L}^{-1}$, existed in the lake in summers, as well as gradients of redox potential, sulfide concentrations ( $>2 \mathrm{mM}$ in bottom layer) and biogenic elements, which are rather characteristic for euxinic meromictic water bodies. Nevertheless, calculations have shown that meromictic stability in the lake is not sufficient for reliable suppression of its full overturn in the autumn period. Winter observations in 2018 confirmed this conclusion. Thus, in hydrochemical terms the lake appeared to be a highly dynamic system with significant vertical gradients of environmental conditions formed and destroyed annually or almost annually. In general, the lake can be apparently attributed to an uncommon and insufficiently studied group of lakes with «spring meromixis» and «irregular mixing» regime.

Key words: freshwater bodies, floodplain lakes, vertical stratification, mixing, gradients of physical and chemical parameters, meromixis, irregular total mixing.

\section{Введение}

Пойменные, и в первую очередь типичные старичные, озера обычно имеют небольшую абсолютную и относительную глубину и большую длину ветрового разгона, и поэтому теоретически должны быть полимиктическими [15]. Однако имеются примеры устойчивой стратификации по крайней мере в некоторых из них, в том числе и очень неглубоких $[12,19]$. В той или иной степени подвержены стратификации даже пойменные водоемы субтропической и экваториальной зон $[8,10]$. Натурные наблюдения указывают на еще более широкое распространение устойчивой летней стра-

(C) Горбунов М.Ю., 2019 тификации в озерах умеренного климата с длительным ледовым покровом. В частности, наши данные показывают, что многие пойменные озера речного происхождения в Волжском бассейне стратифицированы в летний период [1]. Причем в ряде таких озер наряду с температурной стратификацией обнаруживается и существенная, более 100 мг/л, разность минерализаций воды между поверхностным и донным слоем, указывающая на предпосылки к формированию меромиктического режима перемешивания. Очевидно, существуют факторы, способствующие устойчивой стратификации таких водоемов, которые не учитываются при поверхностном анализе. 
Поскольку речные поймы - высокопродуктивные ландшафты, то пойменные озера получают значительные количества органического вещества и биогенных элементов с поверхностным и почвенным притоком. Они имеют высокую биологическую продуктивность. В результате этого, в условиях стратификации в их придонных слоях происходит быстрое истощение кислорода и формирование восстановительных условий в результате накопления в грунтах и придонной водной массе продуктов анаэробного дыхания бактерий. Следствием этого, как правило, является формирование микробного барьера на границе аэробной и анаэробной зон. Этот барьер формируется из аэробных фототрофов (водорослей), хемолитотрофных бактерий и аноксигенных фототрофных бактерий, которые используют соединения, диффундирующие из нижележащих слоев, и тем самым препятствуют возврату продуктов трансформации осажденных веществ в аэробные поверхностные слои [3].

В 2005 году мы обнаружили наличие стратификации с эвксинной аноксией в гиполимнионе одного из пойменных водоемов бассейна Дона, озера Тахтарка в окрестностях города Павловска Воронежской области, и значительного развития аноксигенных фототрофных бактерий в зоне редоксклина. Полученные данные указывали на высокую степень вертикальной гетерогенности. Они даже позволяли предполагать меромиктический характер стратификации в озере. Поэтому озеро было исследовано на протяжении еще нескольких лет. В данной статье представлены результаты исследования вертикальной структуры физико-химических характеристик в озере Тахтарка, и обсуждаются особенности его стратификации.

\section{Материалы и методы}

Объект исследования. Озеро Тахтарка - крупное пойменное озеро в 2,5 км северо-западнее города Павловска в междуречье рек Дона и Ocереди. Озеро имеет сложную форму, напоминающую искаженную букву Х. Его западная часть подковообразной формы, очевидно, имеет старичное происхождение, причем следы старого русла Дона прослеживаются в рельефе. Две восточные ветви, возможно, представляют собой следы старого устья реки Осередь. Северо-восточная ветвь в настоящее время большей частью пересохла, а оставшаяся часть полностью заросла гелофитной растительностью.

Площадь озера - около 14 га, его максимальная и средняя глубина неизвестны, так как батиметрическая съемка не проводилась. В последние годы озеро постепенно пересыхает и теряет глубину. Так, в 2005 году в точке отбора проб мы обнаружили глубину 5,5 м, а в 2016 в той же точке глубина уменьшилась до 3,8-4 м. По сравнению с 80 годами площадь озера за счет заиливания и осушения мелководий сократилась примерно на треть.

Поскольку озеро расположено в пойме Дона, то оно полностью покрывается полыми водами при высоких весенних половодьях. При средних уровнях половодий заполняется при снеготаянии. Однако при частых в последние годы растянутых весенних паводках уровень воды может не достигать величин, достаточных для выхода воды на пойму, и в такие годы водная масса озера не обновляется за счет паводковых вод.

Отбор проб. Исследования озера проводили 814 августа 2005 года, 13 июля 2007 года, 11 августа 2008 года и 12 августа 2016 года. Параметры, определявшиеся в разные годы, суммированы в таблице 1. Пробы отбирались в локальной области наибольшей глубины в северо-западной ветви озера. В 2005 году пробы были отобраны батометром объемом 3 л и высотой 30 см с шагом 0,5 м, в последующие годы - тонкослойным пробоотборником с шагом от 0,1 м в области скачка окисли-

Таблица 1

Список параметров, определявшихся в озере Тахтарка в разные годы исследования

\begin{tabular}{|l|c|c|c|c|}
\hline & 2005 & 2007 & 2008 & 2016 \\
\hline Температура & + & + & + & + \\
Растворенный кислород & + & + & + & + \\
pH & - & - & - & + \\
Еh & - & - & - & + \\
Сульфиды & + & + & - & + \\
Электропроводность & - & - & + & + \\
Содержание основных ионов & + & - & - & + \\
Биогенные элементы & + & - & - & + \\
\hline
\end{tabular}


тельно-восстановительного потенциала до 1 м в приповерхностном слое. Концентрация кислорода в 2005-2007 годах определялась иодометрическим титрованием, в 2008 и 2016 годах - с помощью оксиметров с погружными кислородными электродами (НІ-9143 в 2008 и Эксперт-001 в 2014) перед началом отбора проб, причем полученные данные использовались для уточнения схемы отбора. Температуру в 2005-2007 годах определяли с помощью «родникового» ртутного термометра, в 2008 и 2016 году - с помощью температурного датчика оксиметров. $\mathrm{pH}$ и Eh определяли только в 2016 году с помощью многопараметрического прибора Эксперт-001 непосредственно после отбора проб. Электропроводность определяли с помощью портативных приборов.

Гидрохимический анализ. Для определения содержания основных ионов и биогенных элементов использовали пробы воды, фильтрованные через нитроцеллюлозные (2005-2007) или стеклянные фильтры с порами 0,5-1,2 мкм. Жесткость, щелочность и содержание Са определяли ручными объемными методами [4]. Сульфаты определяли турбидиметрически [4] или хроматным методом [9], сульфиды - с диэтил-парафенилен-диамином [16], хлориды - роданидным методом [7], аммоний - фенол-гипохлоритным методом по Солорзано [18], общее железо - с о-фенантролином, кремний и фосфор - по образованию синих гетеромолибденовых комплексов после восстановле-

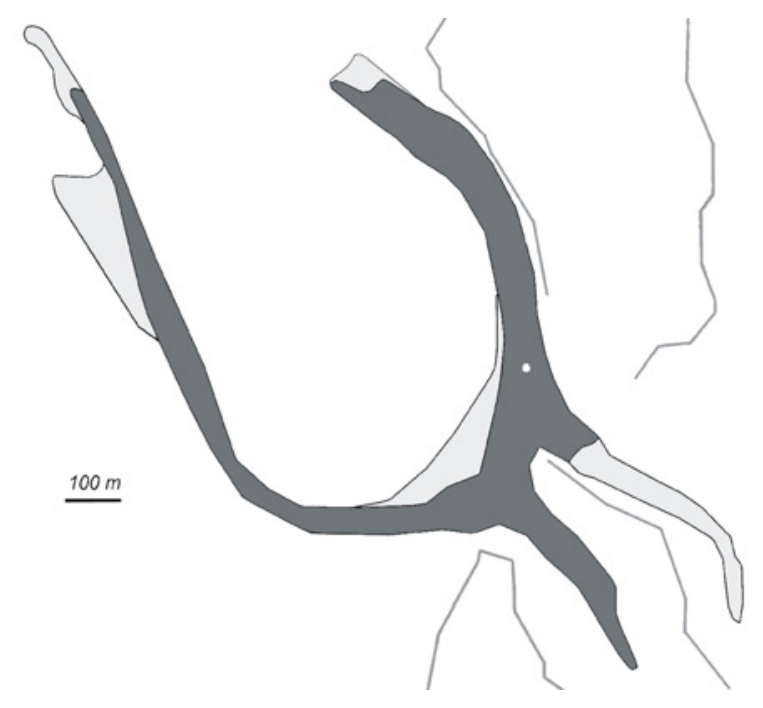

Рис. 1. Схема озера Тахтарка

Светло-серым цветом показаны участки, осушенные и заросшие гелофитной растительностью с начала 1980-х годов. Серые линии - проселочные дороги. Точкой указано место отбора проб. ния метолом и аскорбатом, соответственно [4], общий фосфор - после окисления персульфатом [13].

Плотность воды была рассчитана по формулам [6]. В качестве критериев стратификации были использованы квадрат частоты плавучести $\mathrm{N}^{2}$ и число Ведденбурна W [15].

\section{Результаты}

Стратификация. В вертикальной термической структуре озера во все даты исследования отсутствовал гомотермический поверхностный слой; в верхнем двухметровом слое температура воды относительно монотонно снижалась на $1-1,5^{\circ} \mathrm{C} / \mathrm{M}$ (рис. 1). С глубины 2-3 м начинался главный термоклин, в котором крутизна снижения температуры достигала $8-11,2^{\circ} \mathrm{C} / \mathrm{M}$. Гиполимнион занимал нижние 1,5 м водного столба в 2005 году и около 0,5 м придонного слоя в остальные годы. Температура воды в нем была довольно высокой, около $15^{\circ} \mathrm{C}$ в 2005 и 2007 году и $11,5-12,5^{\circ} \mathrm{C}$ в 2008 и 2016 году.

За исключением 2005 года поверхностный слой воды до глубины 1,5 м был пересыщен кислородом. В 2007 году его концентрация на глубине 0,5 м достигала $212 \%$ насыщения, в 2016 на глубине 1 м - $174 \%$. Ниже концентрация кислорода снижалась, и к верхней границе термоклина он полностью истощался. Одновременно в воде начинали регистрироваться сульфиды, концентрация которых в придонном слое достигала 21 мг/л (2007) - 89 мг/л (2005).

Общее содержание солей (TDS, по сумме главных ионов) оставалось постоянным выше главного термоклина, а ниже значительно увеличивалось к придонному слою с 385 до 832 мг/л в 2005 году и с 361 до 804 мг/л в 2016 году.

В феврале 2018 года было проведено зимнее обследование озера Тахтарка. Исследование показало, что озеро полностью перемешалось в осенний период: вся водная толща была аэрированной и лишена сероводорода и сульфидов. Тем не менее, в озере отмечалась существенная стратификация по минерализации; электропроводность возрастала от 560 мкСм/см на глубине 0,5 м до 640 мкСм/см на глубине 3,5 м, что соответствует разности минерализаций 115 мг/л.

Гидрохимический состав. В 2005 году состав воды озера на всех глубинах соответствовал типичному для региона $\mathrm{HCO}_{3} / \mathrm{Ca}$ классу. Однако содержание сульфатов в воде было довольно велико, достигая в поверхностном слое 50 мг/л или 20 экв\%, концентрация щелочных металлов составляла $25 \%$ во всем водном столбе, хлоридов - 


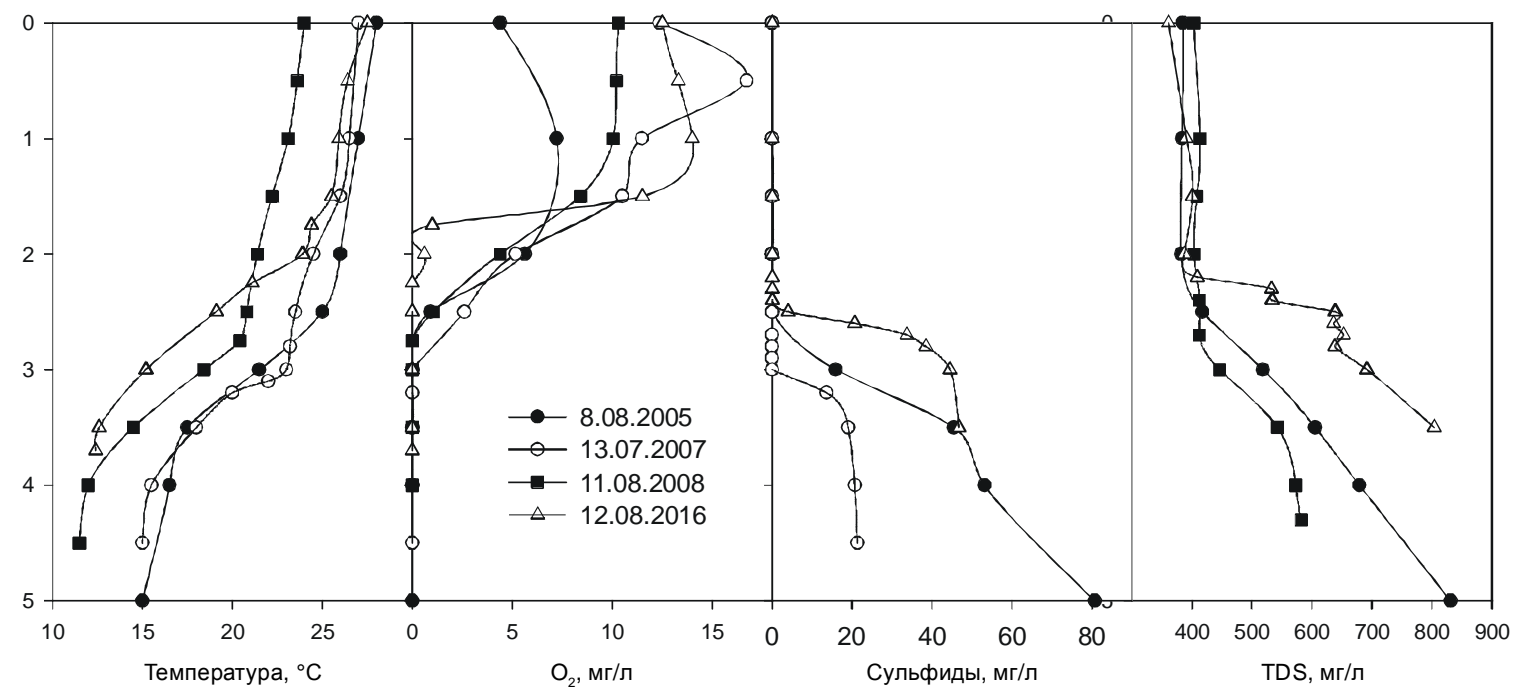

Puc. 2. Вертикальное распределение температуры, концентраций растворенного кислорода и сульфидов и общего содержания солей (TDS) в разные годы исследования. В 2008 году TDS был рассчитан по величинам электропроводности, в 2005 и 2016 годах - как сумма основных катионов и анионов

Таблица 2

Доли основных анионов и катионов (экв\%) в озере Тахтарка в 2005 и 2016 году

\begin{tabular}{|c|c|c|c|c|c|c|c|}
\hline \multirow{2}{*}{$\begin{array}{c}\text { Глубина, } \\
\text { м }\end{array}$} & $\begin{array}{c}\text { Сумма } \\
\text { анионов } \\
\text { (мэкв) }\end{array}$ & \multicolumn{7}{|c|}{ Доли главных ионов (экв\%) } \\
\cline { 2 - 8 } & $\mathrm{HCO}_{3}^{-}$ & $\mathrm{SO}_{4}^{2-}$ & $\mathrm{Cl}^{-}$ & $\mathrm{Ca}^{2+}$ & $\mathrm{Mg}^{2+}$ & $\mathrm{Na}^{+}+\mathrm{K}^{+}$ \\
\hline \multicolumn{7}{|c|}{2005} \\
\hline 0 & 5,13 & 69,4 & 20,3 & 10,3 & 50,7 & 25,0 & 24,3 \\
\hline 2 & 5,10 & 70,6 & 19,0 & 10,5 & 49,4 & 27,4 & 23,2 \\
\hline 3 & 6,85 & 73,6 & 13,9 & 12,5 & 53,7 & 20,4 & 25,8 \\
\hline 5 & 10,79 & 83,8 & 0,9 & 15,4 & 58,9 & 15,6 & 25,5 \\
\hline \multicolumn{7}{|c|}{2016} \\
\hline 0 & 5,20 & 32,3 & 44,9 & 22,8 & 41,7 & 22,4 & 35,9 \\
\hline 2 & 5,54 & 36,1 & 44,4 & 19,5 & 42,8 & 25,4 & 31,8 \\
\hline 2,5 & 8,72 & 57,8 & 26,7 & 15,5 & 50,7 & 21,7 & 27,6 \\
\hline 3 & 9,25 & 73,5 & 10,6 & 15,9 & 58,7 & 22,6 & 18,8 \\
\hline 3,5 & 10,53 & 78,2 & 7,1 & 14,6 & 55,7 & 17,6 & 26,7 \\
\hline
\end{tabular}

10-15\%. С глубиной наблюдалось снижение концентрации сульфатов до их практически полного отсутствия $(<1 \%)$ в придонном слое. Одновременно увеличивались щелочность, концентрации ионов кальция и хлоридов, а концентрация ионов магния, возрастая с 15 до 20 мг/л по абсолютной величине, в относительных величинах снижалась с 25 до 16 экв\%.

В 2016 году поверхностный слой озера по составу стал соответствовать смешанному $\mathrm{SO}_{4}-\mathrm{HCO}_{3} / \mathrm{Ca}-\mathrm{Na}$ классу. Придонный слой по прежнему принадлежал к $\mathrm{HCO}_{3} / \mathrm{Ca}$ классу, однако концентрация сульфатов в нем увеличилась до 7 экв\%. Относительные концентрации хлоридов и ионов щелочных металлов в поверхностном слое увеличились с 10 до 25 экв\% и с 24 до 36 экв\%, но в придонном слое остались почти неизменными.

Хотя содержание сульфатов в оба года снижалось ко дну, содержание общей серы (сумма сульфатов и сульфидов) увеличивалось с 0,5 до 2,4 мМ в 2005 году и с 1,17 до 1,75 мМ в 2016 году.

В целом, концентрация гидрокарбонатов в озере в 2016 году значительно снизилась по сравнению с 2005 годом, а сульфатов - увеличилась при практически неизменных величинах общей минерализации поверхностного и придонного слоя.

Стабильность. Исходя из данных о температуре и общей минерализации (солености) воды, были рассчитаны величины плотности воды. На их основе определена величина частоты плавуче- 


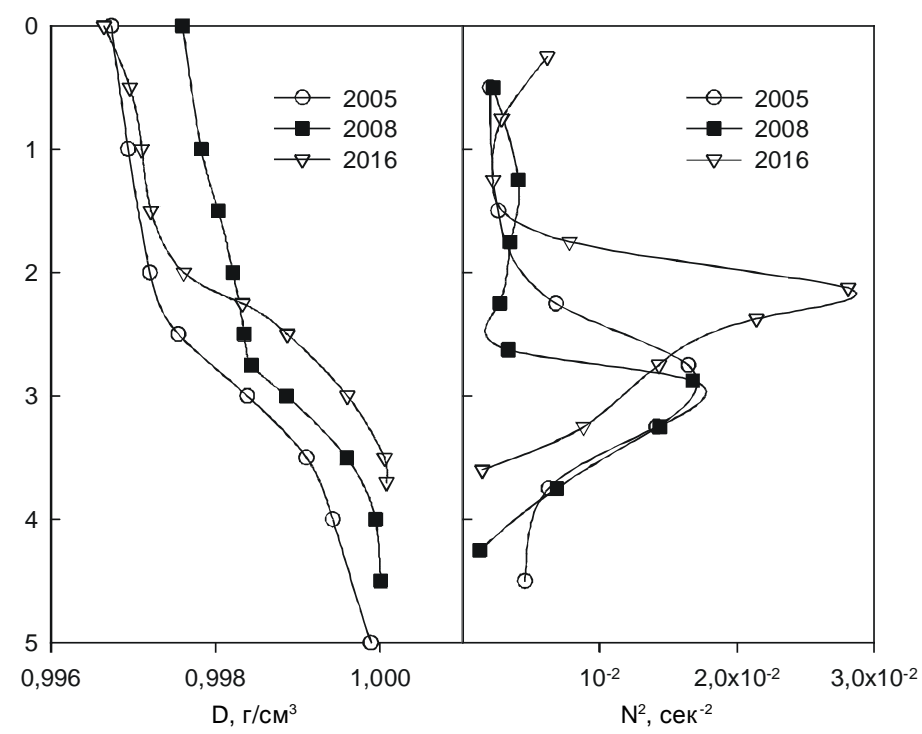

Puc. 3. Плотность воды $\mathrm{D}$ и квадрат частоты плавучести $\left(\mathrm{N}^{2}\right)$ в озере Тахтарка в 2005-2016 годах

сти (частота Брента-Вяйсяля), квадрат которой характеризует стабильность водного слоя, и числа Веддербурна, отражающего возможность апвеллинга пикноклина под действием ветра заданной скорости, приводящего к активному механическому перемешиванию. Как видно из полученных результатов (рис. 3), глубина зоны максимальной стабильности существенно поднялась в 2016 году по сравнению с 2000-ми годами с 3 м до 2,1-2,2 м. Значения числа Веддербурна $\mathrm{W}$ для глубины максимальной стабильности и скорости ветра $10 \mathrm{~m} /$ сек были равны 3,57; 2,72 и 2,19 в 2005, 2008 и 2016 годах, соответственно. Таким образом, хотя величина частоты плавучести в зоне хемоклина была стабильной в 2005 и 2008 году, а в 2016 году даже существенно увеличилась, озеро со временем становилось все менее устойчивым к апвеллингу пикноклина, и, следовательно, к ветровому перемешиванию, но число Веддербурна все же превышало пороговое значение $(\mathrm{W}=1)$, при котором пикноклин достигает поверхности. Расчеты показывают, что «меромиктическая» составляющая стабильности в озере была низкой; только 6-11\% разности плотности воды между придонным и поверхностным слоями было обусловлено разностью TDS. В 2005 году при обнаруженном плотностном расслоении озеро все же могло остаться неперемешиваемым в условиях гомотермии при ветре 10 м/сек $(\mathrm{W}=1,13$ для глубины 5 м); но в 2008 и 2016 году оно неизбежно должно было перемешаться до дна.

Биогенные элементы. Концентрации биогенных элементов были определены только в 2005 и 2016 году. В 2005 году концентрация общего фосфора в поверхностном слое составляла 110-
150 мкг/л, а к придонному слою возрастала до 1,05 мг/л (рис. 4). Минеральный фосфор составлял 45-60\% общего фосфора в поверхностных слоях, и подавляющую часть, до $100 \%$ общего - в придонных. В 2016 году содержание фосфора в поверхностном слое существенно снизилось: минерального - ниже порога определения, общего - до 6-10 мкг/л. В придонном слое, напротив, содержание общего фосфора увеличилось по сравнению с 2005 годом до 1,3 мг/л, однако содержание минерального - понизилось до 0,8 мг/л.

Содержание кремния изменялось аналогично фосфору: в оба года оно значительно возрастало от поверхности ко дну, причем в 2015 году в поверхностном слое снизилось, а в придонном - заметно повысилось по сравнению с 2005 годом. Содержание железа было невелико и в оба года не превышало 0,4 мг/л. Его максимум в оба года наблюдался в области контакта аэробной и анаэробной водных масс на глубинах 2,5-3,5 м в 2005 и 2,3-2,7 м в 2016 году. Определение содержания аммонийного азота было проведено только в 2016 году. Его средняя концентрация в поверхностном слое составляла 0,05 мг/л, к придонному слою она возрастала до 2,7-2,8 мг/л. Это увеличение было немонотонным, а с промежуточным максимумом на глубине 2,6 м (рис. 4).

\section{Обсуждение}

Представленные данные показывают, что в озере Тахтарка во все даты исследования наблюдалось вертикальное расслоение по температуре, за исключением 2007 года, когда данные отсутствовали по минерализации воды. Это приводило к плотностной стратификации водной толщи, и, 

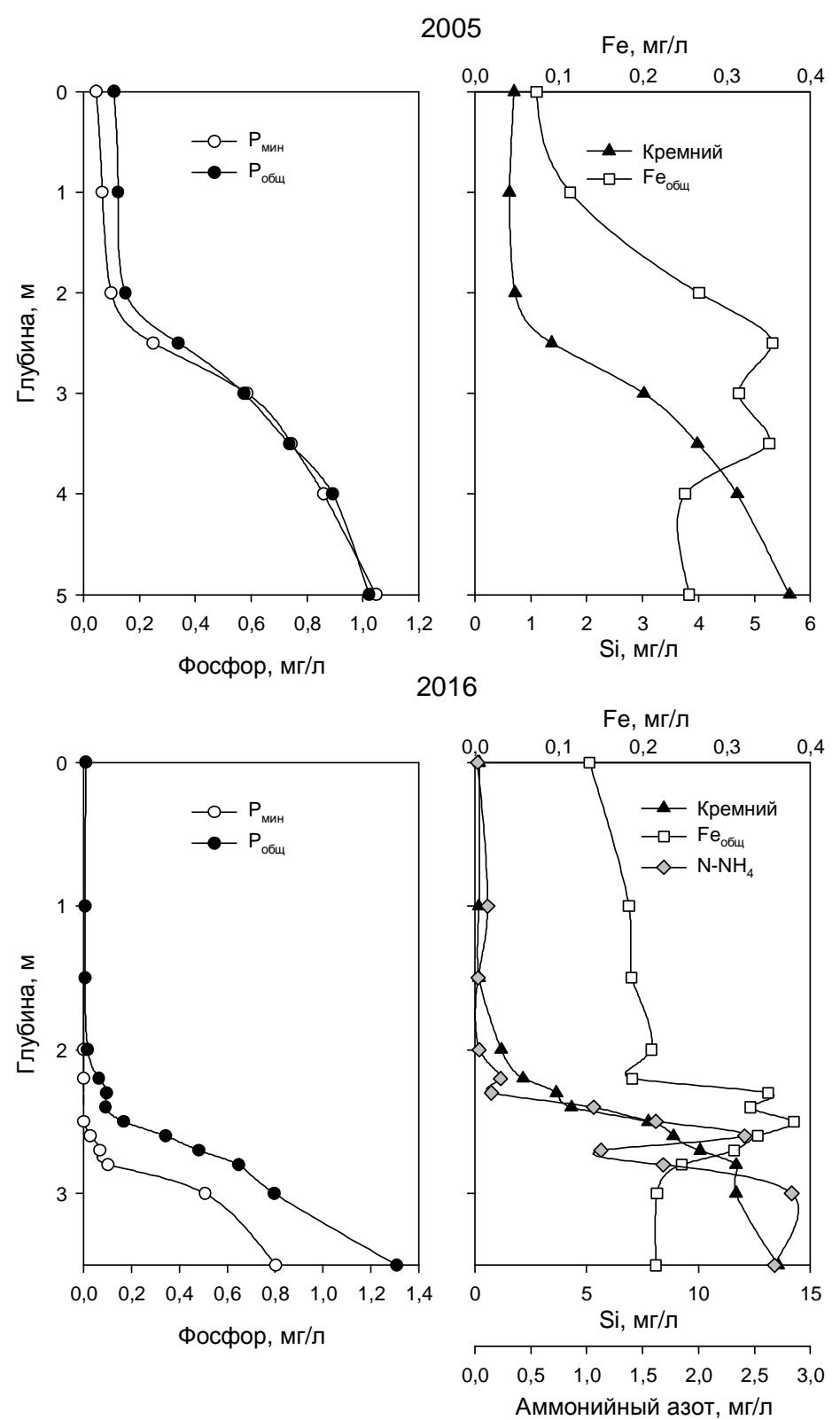

Puc. 4. Вертикальное распределение биогенных элементов в озере Тахтарка в августе 2005 и 2016 года

вследствие этого, к подавлению ее полного перемешивания и формированию вторичных градиентов: кислорода и сульфидов, окислительно-восстановительного потенциала, концентраций биогенных элементов и других экологически значимых параметров.

Стабильность стратификации в озере подтверждается величинами числа Веддербурна, превышающими 2. Хотя использованная при расчете числа Веддербурна скорость ветра 10 м/сек, вдвое меньше рекомендованной в работе [15]. Эта величина, на мой взгляд, адекватно отражает метеорологические условия региона. Так, по данным сайта gismeteo.ru, среднесуточная скорость ветра в окрестностях озера, в мае-сентябре 2016 года никогда не превышала 7 м/сек, и в среднем составляла менее 3 м/сек. Значительная разница минерализации и различие в составе главных ионов между поверхностным и придонным слоем озера, высокие концентрации биогенных элементов и сульфидов в придонном слое, а также стабильный дефицит сульфатов в гиполимнионе также косвенно указывают на длительную устойчивую стратификацию в озере.

Несмотря на то, что в отдельные годы разность минерализаций между поверхностным и придонным слоем превышала 400 мг/л, градиент минерализации в озере, согласно расчетам, недостаточен 
для предотвращения полного перемешивания. Таким образом, хотя в озере наблюдаются предпосылки к формированию меромиктического режима (круглогодичного отсутствия полного перемешивания), малая глубина озера и значительная длина ветрового разгона в нем, очевидно, все же препятствуют его установлению. Поэтому градиент минерализации заново формируется в озере ежегодно или почти ежегодно.

В озерах с ежегодным ледовым периодом вертикальная стратификация гидрохимического состава воды может формироваться в подледный период за счет вымораживания солей из ледового покрова во время его роста и формирования опресненного поверхностного слоя после его таяния [10]. Вымораживание солей при образовании ледового покрова, очевидно, внесло определенный вклад в наблюдавшийся в феврале 2018 года градиент минерализации, но поскольку толщина льда в озере во время наблюдения составляла лишь $20 \mathrm{~cm}$, оно не может полностью объяснить обнаруженное обогащение солями придонного слоя. Поэтому, возможно, в формировании вертикального градиента минерализации в озере участвует креногенный механизм (т.е. поступление в придонный слой высокоминерализованных вод из донных источников). В пользу этого косвенно свидетельствует высокая минерализация воды реки Осередь (1450 мг/л в межень 2016 г.), очевидно, указывающая на высокую величину TDS грунтовых вод региона.

Еще одним фактором, способствующим формированию градиента минерализации, является биогенная седиментация минеральных осадков, в первую очередь карбоната кальция, из эпилимниона в придонный слой. На действие этого фактора в озере Тахтарка указывает наблюдающийся в нем в летний период высокий рН (8,8-9,3 в 2016 г.) воды эпилимниона, связанный, судя по пересыщению кислородом, с интенсивной фотосинтетической фиксацией $\mathrm{CO}_{2}$. Повышение $\mathrm{pH}$ приводит к появлению в воде карбонат-ионов и превышению порога растворимости карбоната кальция. Последний выпадает в осадок и осаждается в придонный слой с более низким $\mathrm{pH}$, где частично остается в донных отложениях, а частично - растворяется в реакции с двуокисью углерода. Косвенно в пользу этого механизма свидетельствует снижение со временем общего содержания неорганического углерода в озере и то, что 65-78\% избытка солей в его придонном слое составляют (по массе) ионы бикарбоната.
Заслуживает отдельного обсуждения также относительно высокая температура в придонном слое озера, свидетельствующая о высокой скорости транспорта тепла в гиполимнион. Она не является уникальной для стратифицированных озер: так, в пруду Ботанического сада города Самара температура в придонном слое в августе также превышала $12{ }^{\circ} \mathrm{C}$; в других стратифицированных малых озерах Среднего Поволжья с близкой глубиной она также достигала близких величин [10]. Однако механизм этого нагрева не вполне ясен.

Известно, что в пресных водах, содержащих гуматы, ИК- и УФ-радиация, составляющая в сумме около половины энергии падающего на поверхность воды излучения, поглощается в верхнем метре воды. Большая часть видимого света в мезои эвтрофных озерах также поглощается в эпилимнионе. Так, в 2016 году квантовая освещенность в озере Тахтарка в ФАР-диапазоне на глубине 2 м составляла чуть более $10^{-2}$ от поверхностной. Однако, в отличие от эпилимниона, тепловая энергия, поступившая в мета- и гиполимнион, не рассеивается путем конвекции и теплообмена с атмосферой, а остается «захваченной» в них на период стратификации. Расчеты показывают, что в течение апреля-августа в водные слои озера ниже хемоклина могло поступить до 5000 ккал/м² световой энергии. Этой энергии достаточно для нагрева слоя мощностью 2 м лишь на $2,5^{\circ} \mathrm{C}$, но не на 7-10 $\mathrm{C}$, как наблюдается реально.

Еще один возможный механизм нагрева донных слоев связан с их гидродинамикой. Ветровое воздействие в озерах приводит к наклону пикноклина; после его прекращения возникают затухающие колебания гиполимниона вокруг его равновесного положения, внутренние сейши [20]. Такие колебания - один из важных факторов, обеспечивающих перемешивание гиполимниона и выравнивание его характеристик по глубине. В озерах с небольшим объемом гиполимниона он, имея постоянный объем, может заметно перемещаться из своего равновесного положения, и входить в контакт с донными отложениями небольших глубин, что неизбежно приводит к нагреву вследствие теплообмена. Этот механизм был недавно непосредственно продемонстрирован в довольно крупном и глубоком озере Киннерет в Израиле [14], и, вероятно, играть еще большую, возможно, определяющую, роль в гидрологических процессах в более мелких стратифицированных озерах, в том числе в озере Тахтарка. 


\section{Заключение}

Озеро Тахтарка имеет многочисленные признаки, сближающие его с эвксинными меромиктическими водоемами. Хотя полученные данные не подтвердили меромиктический характер перемешивания, его отсутствие объясняется почти исключительно морфометрическими характеристиками: при большей глубине и меньшей длине ветрового разгона озеро неизбежно перешло бы к меромиктии, как это, например, наблюдается в пруду Ботанического сада города Самара [2]. В сложившихся условиях в озере весьма вероятны ежегодные пропуски весеннего, а в отдельные годы с благоприятными метеорологическими условиями, возможно, и осеннего полного перемешивания. Озеро можно классифицировать как водоем с «весенним меромиксисом» [17], или «нерегулярным перемешиванием» [11]. Из-за значительно более продолжительного периода стратификации в сравнении с димиктическими озерами умеренной зоны, подобные озера, несмотря на наличие механизмов рециркуляции [5], действительно очень схожи с меромиктическими, что позволяет говорить о наличии в них «элементов меромиксиса».

Однако, если в классических меромиктических озерах высокие вертикальные градиенты условий среды складываются на протяжении многих лет, то в озере Тахтарка лишь немногим меньшие градиенты разрушаются и формируются ежегодно или почти ежегодно.

Таким образом, озеро представляет собой очень динамичную в гидрохимическом плане экосистему. В связи с его необычным гидрохимическим и гидрологическим режимом этот и подобные водоемы, очевидно, заслуживают более пристального изучения.

\section{СПИСОК ЛИТЕРАТУРЫ}

1. Горбунов М. Ю. Вертикальная стратификация водных масс в малых озерах лесостепного Поволжья / М. Ю. Горбунов // Известия Самарского научного центра РАН. - 2007. - T. 9, № 4. - C. 973-985.

2. Горбунов М. Ю. Характеристика абиотических условий в экосистеме Нижнего пруда Ботанического сада Самарского университета / М. Ю. Горбунов, М. В. Уманская, Е. С. Краснова // Бюллетень Самарская Лука. - 2007. - Т. 16, № 1-2(19-20). - С. 131-143.

3. Заварзин Г. А. Введение в природоведческую микробиологию / Г. А. Заварзин, Н. Н. Колотилова. Москва : Университет, 2001. - 256 с.

4. Унифицированные методы анализа вод / под ред. Ю. Ю. Лурье. - Москва : Химия, 1973. - 376 с.
5. Boehrer B. Stratification of Lakes / B. Boehrer, M. Schultze // Reviews of Geophysics. - 2008. - Vol. 46. No. 2006RG000210. -27 p.

6. Chen C. T. Thermodynamic properties for natural waters covering only the limnological range/ C. T. Chen, F. J. A. Millero // Limnology and Oceanography. - 1986. Vol. 31, No. 3. - P. 657-662.

7. Crockson R. A. A rapid colorimetric method for the estimation of urinary chlorides / R. A. Crockson // Journal of clinical pathology. - 1963. - Vol. 16, No. 5. - P. 473-475.

8. Esteves F. A. Considerations on the ecology of wetlands with emphasis on brasilian floodplain ecosystems / F. A. Esteves // Oecol. Bras. - 1998. - Vol. 4, No. 1. P. 111-135

9. Golterman H. L. Colorimetric determination of sulphate in freshwater with a chromate reagent / H. L. Golterman, I. D. G. Bierbrauwer - Würtz // Hydrobiologia. - 1992. - Vol. 228, No. 2. - P. 111-115.

10. Gribben D. L. Anoxygenic phototrophic bacteria and aerobic phototrophs in Normans Lagoon, a 'billabong' adjacent to the Murray River, south-eastern Australia / D. L. Gribben, G. N. Rees, R. L. Croome // Lakes Reservoirs : Research and Management. - 2003. - Vol. 8, No. 2. - P. 95-104.

11. Hakala A. Meromixis as a part of lake evolution observations and revised classification of true meromictic lake in Finland / A. Hakala // Boreal Environment Research. - 2004. - Vol. 9, No. 1. - P. 37-53.

12. Lake stratification in the Carpathian basin and its interesting biological consequences / Borics G. [et al.] // Inland Waters. - 2015. - Vol. 5, No. 2. - P. 173-186.

13. Menzel D. W. The measurement of total phosphorus in seawater based on the liberation of organically bound fractions by persulfate oxidation / D. W. Menzel, N. Corwin // Limnol. Oceanogr. - 1965. - Vol. 10, No. 2. - P. 280-282.

14. Nishri A. The mechanism of hypolimnion warming induced by internal waves / A. Nishri, A. Rimmer, Yu. Lechinsky//Limnol. Oceanogr. - 2015. - Vol. 60, No. 4. - P. 146-1476.

15. Padisa'k J. Shallow lakes: The absolute, the relative, the functional and the pragmatic. / J. Padisa'k, C. S. Reynolds // Hydrobiologia. - 2003. - Vol. 506-509. P. 1-11.

16. Rees T. D. The determination of trace amounts of sulphide in condensed steam with NN-diethyl-pphenylenediamine / T. D. Rees, A. B. Gyllenspetz, A. C. Docherty //Analyst. - 1971. - Vol. 96, No. 1140. P. 201-208.

17. Salonen K. Autumnal and vernal circulation of small forest lakes in Southern Finland / K. Salonen, L. Arvola, M. Rask // Verhandlungen der Internationalen Vereinigung fur Theoretische und Angewandte Limnologie. - 1984. Vol. 22(1). - P. 103-107.

18. Sororzano L. Determination of ammonia in natural waters by the phenol hypochlorite method / L. Sororzano / / Limnology and Oceanography. - 1969. - Vol. 14, No. 5. P. 799-801. 
19. Stratification analysis of the O'hala'sz ox-bow of the River Tisza ( Kisköre Reservoir, Hungary) / Nagy M.T. [et al.] // Hydrobiologia. - 2003. - Vol. 506, No. 1-3. P. 37-44.

20. Wetzel R. G. Limnology / R. G. Wetzel. Philadelphia; London; Toronto : W.B. Sanders Co., 1975. $-743 \mathrm{p}$.

\section{REFERENCES}

1. Gorbunov M. YU. Vertikal'naya stratifikatsiya vodnykh mass v malykh ozerakh lesostepnogo Povolzh'ya / M. YU. Gorbunov // Izvestiya Samarskogo nauchnogo tsentra RAN. - 2007. - T. 9, № 4. - S. 973-985.

2. Gorbunov M. YU. KHarakteristika abioticheskikh usloviy v ekosisteme Nizhnego pruda Botanicheskogo sada Samarskogo universiteta / M. YU. Gorbunov, M. V. Umanskaya, E. S. Krasnova // Byulleten' Samarskaya Luka. 2007. - T. 16, № 1-2(19-20). - S. 131-143.

3. Zavarzin G. A. Vvedeniye v prirodovedcheskuyu mikrobiologiyu / G. A. Zavarzin, N. N. Kolotilova. - Moskva : Universitet, 2001. - $256 \mathrm{~s}$.

4. Unifitsirovannyye metody analiza vod / pod red. YU. YU. Lur'ye. - Moskva : KHimiya, 1973. - 376 s.

5. Boehrer B. Stratification of Lakes / B. Boehrer, M. Schultze // Reviews of Geophysics. - 2008. - Vol. 46. No. 2006RG000210. - 27 p.

6. Chen C. T. Thermodynamic properties for natural waters covering only the limnological range/ C. T. Chen, F. J. A. Millero // Limnology and Oceanography. - 1986. Vol. 31, No. 3. - P. 657-662.

7. Crockson R. A. A rapid colorimetric method for the estimation of urinary chlorides / R. A. Crockson // Journal of clinical pathology. - 1963. - Vol. 16, No. 5. - P. 473-475.

8. Esteves F. A. Considerations on the ecology of wetlands with emphasis on brasilian floodplain ecosystems / F. A. Esteves // Oecol. Bras. - 1998. - Vol. 4, No. 1. P. 111-135.

9. Golterman H. L. Colorimetric determination of sulphate in freshwater with a chromate reagent / H. L. Golterman, I. D. G. Bierbrauwer- Würtz // Hydrobiologia. - 1992. - Vol. 228, No. 2. - P. 111-115.

10. Gribben D. L. Anoxygenic phototrophic bacteria and aerobic phototrophs in Normans Lagoon, a 'billabong'

\section{Горбунов Михаил Юрьевич}

кандидат биологических наук, старший научный сотрудник лаборатории экологии простейших и микроорганизмов Федерального государственного бюджетного учреждения науки Институт экологии Волжского бассейна Российской академии наук, г. Тольятти, E-mail: myugor1960@gmail.ru adjacent to the Murray River, south-eastern Australia / D. L. Gribben, G. N. Rees, R. L. Croome // Lakes Reservoirs : Research and Management. -2003. - Vol. 8, No. 2. - P. 95-104.

11. Hakala A. Meromixis as a part of lake evolution observations and revised classification of true meromictic lake in Finland / A. Hakala // Boreal Environment Research. - 2004. - Vol. 9, No. 1. - P. 37-53.

12. Lake stratification in the Carpathian basin and its interesting biological consequences / Borics G. [et al.] // Inland Waters. - 2015. - Vol. 5, No. 2. - P. 173-186.

13. Menzel D. W. The measurement of total phosphorus in seawater based on the liberation of organically bound fractions by persulfate oxidation / D. W. Menzel, N. Corwin // Limnol. Oceanogr. - 1965. - Vol. 10, No. 2. - P. 280-282.

14. Nishri A. The mechanism of hypolimnion warming induced by internal waves / A. Nishri, A. Rimmer, Yu. Lechinsky // Limnol. Oceanogr. - 2015. - Vol. 60, No. 4. - P. 146-1476.

15. Padisak J. Shallow lakes: The absolute, the relative, the functional and the pragmatic. / J. Padisak, C. S. Reynolds // Hydrobiologia. - 2003. - Vol. 506-509. P. 1-11.

16. Rees T. D. The determination of trace amounts of sulphide in condensed steam with NN-diethyl-p-phenylenediamine / T. D. Rees, A. B. Gyllenspetz, A. C. Docherty // Analyst. - 1971. - Vol. 96, No. 1140. - P. 201-208.

17. Salonen K. Autumnal and vernal circulation of small forest lakes in Southern Finland / K. Salonen, L. Arvola, M. Rask // Verhandlungen der Internationalen Vereinigung fur Theoretische und Angewandte Limnologie. - 1984. Vol. 22(1). - P. 103-107.

18. Sororzano L. Determination of ammonia in natural waters by the phenol hypochlorite method / L. Sororzano // Limnology and Oceanography. - 1969. - Vol. 14, No. 5. P. 799-801.

19. Stratification analysis of the Ohalasz ox-bow of the River Tisza ( Kisköre Reservoir, Hungary) / Nagy M.T. [et al.] // Hydrobiologia. - 2003. - Vol. 506, No. 1-3. P. 37-44.

20. Wetzel R. G. Limnology / R. G. Wetzel. - Philadelphia; London; Toronto : W.B. Sanders Co., 1975. - 743 p.

Gorbunov Mikhail Yurievitch

Candidate of Biological Sciences, Senior Researcher of the Laboratory of ecology of protozoa and microorganisms, Federal State Budgetary Institution of Science Institute of Ecology of Volga Basin, Russian Academy of Sciences, Tol'yatti, E-mail: myugor1960@gmail.ru 